\title{
Gone or just out of sight? The apparent disappearance of aromatic litter components in soils
}

\author{
Thimo Klotzbücher ${ }^{1}$, Karsten Kalbitz ${ }^{2}$, Chiara Cerli ${ }^{3}$, Peter J. Hernes ${ }^{4}$, and Klaus Kaiser ${ }^{1}$ \\ ${ }^{1}$ Soil Science and Soil Protection, Martin Luther University Halle-Wittenberg, von-Seckendoff-Platz 3, \\ 06120 Halle (Saale), Germany \\ ${ }^{2}$ Institute of Soil Science and Site Ecology, Technical University Dresden, Pienner Strasse 19, \\ 01737 Tharandt, Germany \\ ${ }^{3}$ Institute of Biodiversity and Ecosystem Dynamics, Earth Surface Science, University of Amsterdam, \\ Postbus 94240, 1090 GE Amsterdam, the Netherlands \\ ${ }^{4}$ Department of Land, Air, and Water Resources, University of California, One Shields Avenue, \\ Davis, California 95616, USA
}

Correspondence to: Thimo Klotzbücher (thimo.klotzbuecher@googlemail.com)

Received: 12 November 2015 - Published in SOIL Discuss.: 18 January 2016

Revised: 7 June 2016 - Accepted: 26 June 2016 - Published: 12 July 2016

\begin{abstract}
Uncertainties concerning stabilization of organic compounds in soil limit our basic understanding on soil organic matter (SOM) formation and our ability to model and manage effects of global change on SOM stocks. One controversially debated aspect is the contribution of aromatic litter components, such as lignin and tannins, to stable SOM forms. In the present opinion paper, we summarize and discuss the inconsistencies and propose research options to clear them.

Lignin degradation takes place stepwise, starting with (i) depolymerization and followed by (ii) transformation of the water-soluble depolymerization products. The long-term fate of the depolymerization products and other soluble aromatics, e.g., tannins, in the mineral soils is still a mystery. Research on dissolved organic matter (DOM) composition and fluxes indicates dissolved aromatics are important precursors of stable SOM attached to mineral surfaces and persist in soils for centuries to millennia. Evidence comes from flux analyses in soil profiles, biodegradation assays, and sorption experiments. In contrast, studies on composition of mineral-associated SOM indicate the prevalence of non-aromatic microbial-derived compounds. Other studies suggest the turnover of lignin in soil can be faster than the turnover of bulk SOM. Mechanisms that can explain the apparent fast disappearance of lignin in mineral soils are, however, not yet identified.

The contradictions might be explained by analytical problems. Commonly used methods probably detect only a fraction of the aromatics stored in the mineral soil. Careful data interpretation, critical assessment of analytical limitations, and combined studies on DOM and solid-phase SOM could thus be ways to unveil the issues.
\end{abstract}

\section{Introduction}

Storage and quality of soil organic matter (SOM) determine many crucial soil properties and the cycling of carbon (C) and essential nutrients through ecosystems. The storage of SOM is determined by plant litter inputs and decomposition processes. Decomposition of SOM is a significant source of atmospheric $\mathrm{CO}_{2}$ and thus a critical parameter in climate models (Schlesinger and Andrews, 2000). Decomposition rates are sensitive to global change factors such as temperature, precipitation, and land use. However, our ability to understand and predict such responses is limited by uncertainties about pathways of organic matter transformation in soil. In particular, the question as to why some SOM components persist in soil for centuries (denoted as "stable SOM" from here on) while others turn over quickly is still puzzling (Schmidt et al., 2011). 
Recent research challenges traditional theories presuming that stable SOM results from neoformation of complex humic polymers in soil ("humification"; Lehmann and Kleber, 2015). Stable SOM rather seems to be composed of relatively simple organic compounds that are protected against biodegradation, e.g., because they are tightly bound to mineral surfaces (Schmidt et al., 2011; Kleber et al., 2015). Herein, we hold to this view but argue that, despite extensive research in the last years, the chemistry and source of compounds incorporated into stable SOM is still largely uncertain. In particular, the importance of aromatic compounds derived from abundant plant litter components, such as lignin and tannins, is controversially debated (Fig. 1). One line of evidence suggests that they are important contributors to stable SOM. It is based primarily on data from research on fluxes and behavior of dissolved organic matter (DOM) in soil; hence, we will denote it as the "dissolved phase line of evidence". A contrasting line of evidence suggests a quick degradation of aromatic compounds in soil derives primarily from analyses of the composition of solid SOM ("solid phase line of evidence"). Herein, we sum up and confront the arguments of the two views and then discuss potential reasons for the controversies (including limitations in analytical methods and process understanding) as well as their implications for our basic understanding of SOM formation.

\section{Dissolved phase line of evidence}

The view that plant-derived aromatics are a major source of stable SOM is based on the following main arguments:

1. DOM produced during litter decomposition and leached into mineral soil is a main source of stable SOM adsorbed on mineral surfaces.

2. Aromatic DOM components produced during litter decomposition are resistant to mineralization and preferentially sorb to mineral surfaces. Hence, they are preferentially stabilized in mineral soil.

3. Root decomposition in mineral soil could be another important source of aromatic DOM components that contribute to stable SOM.

\subsection{Argument 1: DOM as a source of stable SOM}

Leaching of DOM is a major pathway for organic matter translocation from forest floor into the topsoil horizons. Estimates for acidic forest soils with permanent forest floor suggest that $25-89 \%$ of the SOM stored in mineral soils derives from DOM (Neff and Asner, 2001; Michalzik et al., 2003; Kalbitz and Kaiser, 2008), based on the typical observation of decreasing DOC fluxes with depth of the mineral soil (a large compilation of data from studies on forest and grassland soils is presented by Neff and Asner, 2001). Two processes can explain the decrease: mineralization and sorption.

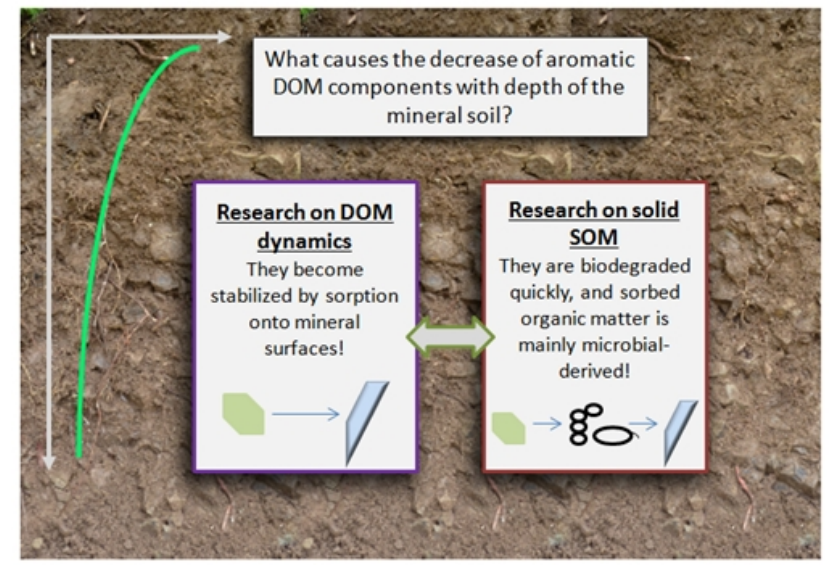

Figure 1. Conflicting views on the fate of soluble aromatics once they enter the mineral soil (see text for references).

Sorption of DOM to mineral surfaces is likely a major process forming stable SOM in many soils. Evidence for its importance comes from findings that the turnover and storage of SOM in mineral soil horizons is related to the contents of reactive secondary minerals (e.g., iron hydrous oxides, short-range ordered aluminum hydroxides). Such relationships have been found across a wide range of soil types (comprehensive data sets have been presented in Torn et al., 1997; Eusterhues et al., 2005; Kögel-Knabner et al., 2008; Kramer et al., 2012; Kleber et al., 2015). Also, higher radiocarbon age of SOM in heavy (i.e., mineral) fractions compared to light density (i.e., organic) fractions indicates that sorption stabilizes organic compounds (see data compilations by Marschner et al., 2008; Kögel-Knabner et al., 2008; Kleber et al., 2015). Density fractionation procedures indicate that the total soil $\mathrm{C}$ associated with minerals in any given location can vary from 30 to $90 \%$ (data compiled in Kleber et al., 2015). The relevance of sorptive stabilization depends on soil properties. Low soil $\mathrm{pH}$ enhances the formation of reactive secondary minerals and favors the formation of strong bonds between organic matter and the mineral surface (Kleber et al., 2015). Most studies cited in the present article examined acidic soils under temperate forests, in which sorptive stabilization clearly should play an important role for the long-term storage of organic matter in soil.

\subsection{Argument 2: preferential stabilization of aromatic DOM components}

Lignin, a macromolecule composed of phenyl propane units, is a major plant cell wall component (Kögel-Knabner, 2002). Typically, lignin concentrations negatively correlate with litter decomposition rates. They are the predominant control on litter decomposition within biomes worldwide (Cornwell et al., 2008), indicating that the lignin macromolecule is among the most persistent litter constituents. Neverthe- 
less, results of recent studies suggest significant chemical alteration and losses of lignin already within the first months and years of litter decomposition (Kalbitz et al., 2006; Preston et al., 2009; Klotzbücher et al., 2011; Duboc et al., 2014). "Degradation" of lignin has to be considered a stepwise process: (i) the first step is the depolymerization of the macromolecule, releasing (mainly aromatic) water-soluble depolymerization products of varying molecular weight; (ii) these products can then be further transformed, and low-molecular-weight compounds are eventually taken up by microorganisms to produce biomass or $\mathrm{CO}_{2}$. Hence, losses of lignin-derived $\mathrm{C}$ during litter decomposition can occur due to leaching of water-soluble products of an incomplete degradation or as $\mathrm{CO}_{2}$. Laboratory incubation tests on water-extractable organic matter from various plant and soil materials suggest that aromatic components are more resistant to mineralization than non-aromatic components (Pinney et al., 2000; Kalbitz et al., 2003a, b; Marschner and Kalbitz, 2003; Don and Kalbitz, 2005; McDowell et al., 2006; Hagedorn and Machwitz, 2007; Fellman et al., 2008; Hansson et al., 2010; Kothawala et al., 2012; Toosi et al., 2012). This suggests that leaching is an important factor in loss of lignin-derived matter during litter decomposition. Consistent with this conceptual model, the typically high UV absorptivity of DOM leached from forest floors (i.e., higher than values found for DOM leached from Oi and Oe horizons) is indicative of a large contribution of resistant aromatic components (Kalbitz et al., 2007; Fröberg et al., 2007).

Another factor for the export of aromatic DOM from forest floors is leaching of tannins. Tannins are water-soluble polyphenols of a molecular weight ranging from 500 to $3000 \mathrm{Da}$. Tannins rapidly leach from fresh litter; most studies suggest losses of $\sim 80 \%$ within the first year of litter decomposition (Kraus et al., 2003).

It has been commonly found that the contribution of components likely derived from lignin and tannins to DOM decreases with depth of the mineral soil (summarized in Table 1) - i.e., the decrease in fluxes of these compounds with depth is more pronounced than the decrease in bulk DOM. One explanation might be intensive biodegradation of aromatics in mineral soil. However, this would contradict results of the DOM biodegradation studies previously discussed. Hence, a more likely explanation is sorption to mineral surfaces. Laboratory sorption experiments support this view; a typical observation is that aromatic DOM components are preferentially sorbed by minerals and soils (Davis and Gloor, 1981; Jardine et al., 1989; McKnight et al., 1992; Dai et al., 1996; Kaiser and Zech, 1997, 2000; Chorover and Amistadi, 2001; Guo and Chorover, 2003; Kalbitz et al., 2005; Kawahigashi et al., 2006; Hunt et al., 2007; Mikutta et al., 2007; Jagadamma et al., 2012; Sodano et al., 2016), and for some soils it has been shown they displace previously bound organic components from mineral surfaces (Kaiser et al., 1996). The degree of preferential sorption may depend on the composition of the soil mineral assemblage. Chorover and
Amistadi (2001) observed that high-molecular-weight aromatic components preferentially sorbed onto goethite, while for montmorillonite no preference for aromatic moieties was observed. A likely reason for the preferential sorption is the large content of carboxyl groups linked to the aromatic rings, which bind to metals at mineral surfaces via ligand exchange reactions.

\subsection{Argument 3: roots as a source of stabilized aromatic SOM}

We have so far focused on DOM leached from aboveground litter. However, roots might also be a crucial source of stable SOM. The contribution of root and aboveground litter as a major source of SOM has been debated in numerous studies, but the available information allows no definite conclusions yet (comprehensive discussions on the topic can be found in Lajtha et al., 2014; Hatton et al., 2015). Presumably, the relative importance of the two types of organic matter input for SOM storage in topsoils differs between ecosystems (Crow et al., 2009) and the importance of root-derived matter increases with soil profile depth (Rumpel et al., 2015).

This raises issue of whether results from aboveground litter decomposition would also apply to root litter decomposition. Data by Crow et al. (2009) suggest that lignin concentrations of roots are in the range of those of leaf and needle litter. Root-derived DOM shows higher concentrations of aromatic compounds than DOM from foliar litter (Hansson et al., 2010; Uselman et al., 2012). Hansson et al. (2010) showed that DOM production during root decomposition occurs in patterns that are similar to those of needle decomposition. Particularly during later decomposition stages, rootderived DOM is enriched in aromatics resistant to mineralization. Hence, available information suggests that root decomposition is just another important source of soluble aromatics in mineral soils. However, to the best of our knowledge, studies to quantify the contribution of root-derived aromatics to DOM fluxes in the field have not yet been conducted. Overall, the available information is limited to data from laboratory experiments and refers to acid temperate forest soils, so that it is not yet possible to draw general conclusions.

\section{Solid phase line of evidence}

Many of the recent conceptual papers on SOM formation are built on the assumption that lignin-derived aromatics disappear quickly in soil, while SOM in mineral soils is dominated by non-aromatic and microbial-derived compounds (Grandy and Neff, 2008; Schmidt et al., 2011; Dungait et al., 2012; Miltner et al., 2012; Cotrufo et al., 2013; Castellano et al., 2015). Empirical support is provided by studies characterizing the chemical structure of solid SOM using a variety of analytical methods. 
Table 1. Evidence from field studies suggesting that dissolved aromatics (products of lignin depolymerization or tannins) disappear quickly once entering mineral soils.

\begin{tabular}{|c|c|c|}
\hline Reference & Study site/soil type & Result \\
\hline Qualls and Haines (1991) & $\begin{array}{l}\text { Oak-hickory forest in mountain region of } \\
\text { North Carolina; soil types: Umbric } \\
\text { Dystrochrept, Typic Hapludult, Typic } \\
\text { Dystrochrept }\end{array}$ & $\begin{array}{l}\text { Selective removal of hydrophobic acids as } \\
\text { DOM percolates through the mineral soil. }\end{array}$ \\
\hline Cronan (1985) & $\begin{array}{l}\text { Forests, northwestern USA; soil types: } \\
\text { Dystrochrept, Haplorthod }\end{array}$ & $\begin{array}{l}\text { Selective removal of hydrophobic acids as } \\
\text { DOM percolates through the mineral soil. }\end{array}$ \\
\hline Zech et al. (1994) & $\begin{array}{l}\text { Spruce forest in Bavaria, Germany; soil } \\
\text { types: Typic Dystrochrepts, Entic } \\
\text { Haplorthods, Typic Haplorthods }\end{array}$ & $\begin{array}{l}\text { Selective removal of lignin-derived phenols } \\
\text { (determined with the } \mathrm{CuO} \text { method) as DOM } \\
\text { percolates through the mineral soil. }\end{array}$ \\
\hline Gallet and Pellissier (1997) & $\begin{array}{l}\text { Bilberry-spruce forest in Alps, France; soil } \\
\text { type: Humoferric Podzol }\end{array}$ & $\begin{array}{l}\text { Selective removal of lignin-derived phenols } \\
\text { (as well as of total phenols) as DOM } \\
\text { percolates through the mineral soil. }\end{array}$ \\
\hline Kaiser et al. (2004) & $\begin{array}{l}\text { Spruce forest in Bavaria, Germany; soil } \\
\text { type: Haplic Arenosol }\end{array}$ & $\begin{array}{l}\text { Selective removal of lignin-derived phenols, } \\
\text { hydrophobic compounds, and total aromatic } \\
\mathrm{C} \text { as DOM percolates through the mineral } \\
\text { soil. }\end{array}$ \\
\hline Dai et al. (1996) & $\begin{array}{l}\text { Spruce forest, Maine; soil type: Aquic } \\
\text { Haplothods }\end{array}$ & $\begin{array}{l}\text { Selective removal of hydrophobic acids and } \\
\text { aromatics }\left({ }^{13} \mathrm{C}-\mathrm{NMR} \text { data) as DOM }\right. \\
\text { percolates through the mineral soil. }\end{array}$ \\
\hline Lajtha et al. (2005) & $\begin{array}{l}\text { Coniferous forest, Oregon, USA; soil type: } \\
\text { Typic Hapludands }\end{array}$ & $\begin{array}{l}\text { Selective removal of hydrophobic acids as } \\
\text { DOM percolates through the mineral soil. }\end{array}$ \\
\hline Sanderman et al. (2008) & $\begin{array}{l}\text { Mediterranean climate; forest and grassland } \\
\text { soils; soil types: Haplustols and } \\
\text { Haplohumults }\end{array}$ & $\begin{array}{l}\text { Decrease in UV absorbance (a measure for } \\
\text { content of aromatics) as DOM percolates } \\
\text { through the mineral soil. }\end{array}$ \\
\hline Hassouna et al. (2010) & $\begin{array}{l}\text { Mediterranean climate; maize field; soil } \\
\text { type: Fluvic Hypercalcaric Cambisol }\end{array}$ & $\begin{array}{l}\text { Decrease in contents of aromatic compounds } \\
\text { (UV absorbance, fluorescence spectroscopy) } \\
\text { in water-extractable organic matter with } \\
\text { depth of the mineral soil. }\end{array}$ \\
\hline Nakashini et al. (2012) & $\begin{array}{l}\text { Beech forest, Japan; soil: "brown forest } \\
\text { soil"" }\end{array}$ & $\begin{array}{l}\text { Decrease in contents of hydrophobic acids in } \\
\text { water-extractable organic matter with depth } \\
\text { of the mineral soil. }\end{array}$ \\
\hline
\end{tabular}

Numerous studies on a wide variety of soil types used the cupric oxide $(\mathrm{CuO})$ method to analyze the distribution of lignin-derived phenols in profiles. A typical observation is that the phenol contribution to SOM decreases (i) from forest floor to A horizons, (ii) with depth of the mineral soil, (iii) with decreasing soil particle size (reviewed in Thevenot et al., 2010) and (iv) with increasing density of soil fractions and hence phenols are contributing little to heavy (i.e., mineral-associated) and old soil fractions (Leifeld and Kögel-Knabner, 2005; Grünewald et al., 2006; Sollins et al., 2009; Kögel-Knabner et al., 2008; Cerli et al., 2012). Similar results are reported by studies using pyrolysis-gas chromatography-mass spectrometry (Gleixner et al., 2002; Nierop et al., 2005; Buurman et al., 2007; Grandy and Neff, 2008; Tonneijck et al., 2010; Rumpel et al., 2012) and tetramethylammonium hydroxide (TMAH) thermochemolysis (Nierop and Filley, 2007; Mason et al., 2012).

Analysis of heavy and clay-sized soil fractions using cross polarization and magic angle spinning (CPMAS) ${ }^{13} \mathrm{C}$ nuclear magnetic resonance spectroscopy $\left({ }^{13} \mathrm{C}-\mathrm{NMR}\right)$ typically finds high peak intensities of alkyl and $\mathrm{O} / \mathrm{N}$ alkyl $\mathrm{C}$ (mostly assigned to polysaccharides and proteins) and low peak intensities of aryl C (mostly assigned to lignin and tannins) (see data compilations by Mahieu et al., 1999; Kögel-Knabner et al., 2008). For instance, in a comprehensive study on Ah horizons from eight European forest sites, O/N alkyl C contributed up to $41-49 \%$ of total peak intensity in the $<2 \mu \mathrm{m}$ fraction, and the peak intensities were on average $10 \%$ higher than those reported for bulk soil; the intensities of aryl $\mathrm{C}$ in the $<2 \mu \mathrm{m}$ fraction contributed $13-15 \%$ of total 
peak intensities, and they were on average $24 \%$ lower than values found for bulk soil (Schöning et al., 2005). Also, studies using near-edge X-ray absorption fine structure (NEXAFS) spectra supported the conclusions drawn from ${ }^{13} \mathrm{C}$ NMR analysis of a significant contribution of microbialderived compounds to SOM at mineral surfaces (Lehmann et al., 2007; Kleber et al., 2011).

Consistent with these findings, the heavy soil fraction is characterized by low $\mathrm{C} / \mathrm{N}$ values close to those of microbial tissues (Kögel-Knabner et al., 2008).

Analysis of microbial-derived polysaccharides by acid hydrolysis suggest an enrichment of these compounds in fine and heavy soil fractions (Kiem and Kögel-Knabner, 2003; Rumpel et al., 2010).

Lignin turnover (i.e., transformation into $\mathrm{CO}_{2}$ or nonlignin products) in temperate arable, grassland, and tropical forest soils has been estimated using a combination of isotopic labeling and compound-specific isotope analysis of lignin-derived aromatics applying the $\mathrm{CuO}$ method. Most of the studies using this approach suggest that the turnover of lignin-derived aromatics is faster than the turnover of bulk SOM (Dignac et al., 2005; Heim and Schmidt, 2007; Heim et al., 2010). A modeling study based on the data by Dignac et al. (2005) suggested that about $90 \%$ of the lignin is mineralized as $\mathrm{CO}_{2}$ or transformed into compounds devoid of lignin-type signatures within 1 year (Rasse et al., 2006). However, a study by Hofmann et al. (2009) suggests that after 18 years, approximately two-thirds of the initial lignin phenols remained in an arable soil. The authors concluded that lignin was preferentially preserved in the soil.

\section{Reasons for the controversies}

\subsection{Analytical limitations}

The controversies in the current literature might (partly) be due to difficulties in the analyses of aromatic OM compounds in soils. Studies on DOM typically use bulk methods for inferring aromatic content, including UV absorbance and fluorescence spectroscopy. Limitations of this research include lack of identification of the source of aromatic compounds and poor quantification of the fluxes. Also, data on contribution of aromatic components to solid SOM are semiquantitative or qualitative.

Commonly applied methods such as $\mathrm{CuO}$ oxidation, pyrolysis, or TMAH thermochemolysis focus on few defined lignin-derived monomers to estimate the overall contribution of lignin. These estimates, however, can largely differ depending on the method applied (Klotzbücher et al., 2011). As outlined by Amelung et al. (2008), compound-specific isotope analysis of lignin-derived compounds with the $\mathrm{CuO}$ method presumably overestimates the turnover rates of lignin as only part of the lignin-derived aromatics can be extracted from soil (incomplete extraction might also be a problem in all analyses of biomarkers, for which turnover rates are typically estimated to be higher than turnover rates of bulk $\mathrm{SOM}$ ). Firstly, $\mathrm{CuO}$ oxidation (as well as conventional pyrolysis or TMAH thermochemolysis) does not completely depolymerize lignin (Johansson et al., 1986; Goňi and Hedges, 1992; Filley et al., 2000). Secondly, lignin-derived aromatics bound to mineral surfaces are only partly assessed by the $\mathrm{CuO}$ method (Hernes et al., 2013). Thirdly, lignin-derived aromatics might be altered in a way that they escape the "analytical window" and cannot be ascribed to a lignin source anymore. For instance, the $\mathrm{CuO}$ method yields a number of aromatic monomers of unknown origin besides the ligninderived monomers (Cerli et al., 2008). These compounds are typically not quantified and are thus not considered in estimates of the SOM composition. Hence, monomer yield is a commonly used but uncertain measure of lignin concentration in soil.

Solid-state CPMAS ${ }^{13} \mathrm{C}$-NMR has been widely used in the last decades to study the composition of SOM. Whether the results are quantitative has been the subject of an intensive debate (see Knicker, 2011). Mineral soil samples are commonly pretreated with hydrofluoric acid (HF) in order to remove paramagnetic minerals that disturb the analysis. The treatment can result in significant losses of SOM, and one might lose important information on SOM adsorbed onto minerals (e.g., SOM losses of 10-30\% in topsoil samples and up to $90 \%$ in subsoil; Eusterhues et al., 2003). Eusterhues et al. (2007) attempted to assess the chemical composition of HF-soluble SOM by comparing CPMAS ${ }^{13}$ C-NMR spectra of untreated and HF-treated soil samples. The data suggest that the composition of HF-soluble SOM varies between soil type and soil horizons. The effect of HF treatment thus produces unpredictable changes in composition and questions the meaning of spectra obtained on HF-treated samples. However, the approach used comes with the uncertainty that in the untreated soil part of the SOM attached to mineral surfaces might have been invisible due to the proximity to paramagnetic material (Kinchesh et al., 1995), while in the HF-treated soil, the same SOM might have become removed during the treatment and thus was no longer detectable. Further uncertainties of CPMAS ${ }^{13} \mathrm{C}$-NMR arise from signal overlapping and a general low sensitivity for aromatic C in soils (e.g., Skjemstad et al., 1996; Mao et al., 2000; Simpson and Simpson, 2012). The common approach used to quantify the relative contribution of different $C$ types to SOM is to integrate and compare peak areas of different spectra regions without considering any non-proportional signal responses (e.g., Kögel-Knabner, 2002). It has been shown that this approach underestimates lignin vs. cellulose in ligno-cellulose isolated from wheat (Gauthier et al., 2002).

By applying Bloch decay, another type of ${ }^{13} \mathrm{C}-\mathrm{NMR}$ technique, one can overcome the problem of the reduced sensitivity for aromatic $\mathrm{C}$. The technique has been applied in studies on pyrogenic organic matter, for which CPMAS ${ }^{13} \mathrm{C}-\mathrm{NMR}$ should be even less sensitive than for lignin as it is more condensed (Golchin et al., 1997; Simpson and Hatcher, 2004; 
Knicker et al., 2005). Bloch decay, however, also comes with problems, such as general low signal intensity. It is not routinely applied in SOM research as it is an extremely timeconsuming experiment and the required instrument time is frequently not available (Simpson and Hatcher, 2004).

\subsection{Limits in process understanding}

The contradictions outlined herein might also suggest gaps in the understanding of SOM turnover processes. Here we argue that, in particular, knowledge about the turnover of SOM at mineral surfaces is insufficient. This is due to the yet uncertain quantitative composition of SOM. In addition, prevailing conceptual ideas and paradigms have been questioned in recent years.

It has been frequently observed that the ${ }^{14} \mathrm{C}$ age of DOM increases with profile depth. Kaiser and Kalbitz (2012) proposed that this can be explained by temporal sorptive immobilization, followed by microbial processing and re-release of altered compounds into soil solution. That would mean the assumption that aromatic compounds are stable after being sorbed onto mineral surfaces could be erroneous. Hence, the microbial processing of sorbed compounds might be the "missing argument" that proves the view of a fast disappearance of aromatic compounds in mineral soil. However, these processes have hardly been studied yet, and empirical evidence for their importance is missing.

Also, root activity might have significant effects on stability and composition of SOM sorbed onto mineral surfaces. The recent study of Keiluweit et al. (2015) showed that root exudation of oxalic acid promotes release of sorbed compounds into soil solution through dissolution of mineral phases. Besides oxalic acid, many other low-molecularweight compounds, including acids, simple sugars, amino sugars, phenolics, and high-molecular compounds (exoenzymes, root cells) are released from living roots (Wichern et al., 2008). Most of the compounds are degraded quickly, but a smaller portion seems to contribute to stable SOM (Nguyen, 2003; Pausch et al., 2013). The rhizosphere is considered a "hotspot" in soil, where microbial processes are not C-limited (Kuzyakov and Blagodatskaya, 2015). Hence, root activity may possibly accelerate the turnover of sorbed plantderived aromatics, and at the same time foster the production and stabilization of microbial-derived compounds. Studies addressing these assumptions are not yet available.

Recent investigations at the submicrometer scale using nano-scale secondary ion mass spectrometry (NanoSIMS) or NEXAFS in combination with scanning transmission Xray microscopy suggest that SOM associated with clay-sized minerals exists in small patches of varying chemical composition (Lehmann et al., 2008; Remusat et al., 2012; Vogel et al., 2014). Distinct patches of predominantly aromatic C can be differentiated from patches dominated by aliphatic $\mathrm{C}$ (Lehmann et al., 2008). Knowledge about processes controlling the submicrometer-scale distribution of SOM on min- eral surfaces is still limited. Some of the patches are cell wall structures of microorganisms, which may contribute to stable SOM as they are composed of insoluble polymers and possibly attach to the mineral surface (Miltner et al., 2012). Hence, stable sorbed organic matter might not only be derived from low-molecular-weight compounds. On the other hand, it needs to be considered that microbial-derived compounds are continuously synthesized at the mineral surface. The microorganisms might use some of the older $\mathrm{C}\left({ }^{14} \mathrm{C}\right.$ age $)$ for synthesis of relatively labile compounds. The age of the $\mathrm{C}$ atoms is thus decoupled from the stability of the organic matter, and microbial-derived compounds may "mimic" a similar or even higher stability than the plant-derived compounds (Gleixner, 2013). Hence, concentrations or ${ }^{14} \mathrm{C}$ age of microbial-derived compounds at mineral surfaces does not per se allow for conclusions on their contribution to stable SOM.

Pyrogenic organic matter is an important source of aromatic compounds in many soils. Despite extensive research efforts, rates, and pathways of pyrogenic organic matter decomposition are still not well established (Schmidt et al., 2011; Kuzyakov et al., 2014). Analyses of benzenecarboxylic acids as molecular markers suggest that aromatic compounds derived from pyrogenic organic matter are transported within soil profiles and bind to mineral surfaces (Haumaier, 2010). The quantitative contribution of pyrogenic organic matter to DOM in soil is, however, still poorly studied (Smebye et al., 2016). Bulk analyses of aromatic matter used in most research on DOM fluxes (i.e., UV absorption) cannot distinguish whether the compounds derive from plant litter or from pyrogenic organic matter. This limits the understanding of the processes controlling turnover of aromatics. If a significant part of aromatic DOM in mineral soil derives from pyrogenic organic matter, the "loss" of plant-litter-derived aromatics in mineral soil would be even more pronounced.

\section{Implications and future research strategies}

The contradictions outlined herein limit our basic understanding on SOM formation, and our ability to model and manage effects of global change on SOM stocks.

For instance, elevated atmospheric $\mathrm{CO}_{2}$ levels can induce increasing concentrations of aromatic components in plant litter (Cotrufo et al., 1994; Tuchman et al., 2002), and this raises the question of whether this causes enhanced or decreasing storage of SOM in mineral soils. If aromatic matter is quickly degraded, and mineral-associated SOM primarily derives from microbial sources (as suggested by the solid SOM line of evidence), a "microbial filter" would control the build-up of stable SOM, which may then be determined by the microbial substrate use efficiency (i.e., the amount of organic $\mathrm{C}$ used by the microbial community to build biomass vs. the amount that is mineralized). As such, Cotrufo et al. (2013) hypothesized that input of labile sub- 
strates fosters the build-up of stable SOM. Available data on effects of litter quality and SOM formation are, however, inconsistent (Castellano et al., 2015), and we think that understanding these effects is in part limited by uncertainties about the incorporation of aromatics into stable SOM.

The issue is also related to the question of links between chemical structure of organic matter and its persistence. It is oftentimes assumed that structural properties of plantderived matter do not determine stable SOM formation. This argument is based on data suggesting that specific compound classes (lignin, cellulose, alkanes, proteins etc.) turn over faster than bulk SOM (Schmidt et al., 2011). However, conclusions of DOM research imply that structure plays a role in the behavior of organic compounds in soil, and eventually their contribution to stable SOM: soluble aromatics may resist oxidation by microbes as they yield less energy than other structures; furthermore, they bind to mineral surfaces due to carboxyl groups attached to the rings.

How could we resolve the controversies? Based on our literature analysis we propose the following research strategies:

- Knowledge on aromatics in soils is limited by the analytical constraints. Quantification of total amounts and sources of aromatics in soil are still problematic. Even if the problems cannot be fully solved with the currently available techniques, there might be strategies to obtain improved estimates. The work of Hernes et al. (2013) provides a first hint about how much lignin might be not accessible to $\mathrm{CuO}$ oxidation analyses. The authors evaluated the extraction efficiency for ligninderived aromatics bound to different minerals. The size of the non-extractable fraction depended on the mineral. Almost all of the aromatics bound to ferrihydrite were extractable, but for kaolinite the non-extractable fraction made up $>40 \%$. But how about extractability in soil under field conditions? Possibly, a combination of tracking of $\mathrm{C}$ isotopes, DOM flux/composition assessment, and analysis of solid-phase SOM composition could provide better estimates of hidden aromatics.

- The causes of the commonly observed decreasing fluxes of aromatic DOM fluxes with depth of the mineral soil need to be re-examined. Are they really mainly the result of sorption to mineral surfaces (as proposed herein in Sect. 2), or do other processes such as the binding of tannins to proteins or mineralization also play a decisive role? Moreover, the presumed microbial processing of sorbed material, causing desorption and subsequent mineralization or further transport in the soil profile, is poorly studied. Knowledge gaps also exist concerning the question whether root activity affects (de)sorption processes. Eventually, these processes might cause loss of aromatic compounds.

- Computer simulations could help to unravel the complex interrelationships between DOM fluxes and solid- phase SOM composition. Recently developed models integrate sorption, DOM transport, and microbial processes (Ahrens et al., 2015). In order to address the problems discussed herein, effects of molecular structure on behavior of the compounds in soil (e.g., differences in mineralization rate and affinity for sorption between aromatics and non-aromatics) could be implemented in the models in order to develop novel hypotheses on turnover of plant-derived aromatics.

Acknowledgements. T. Klotzbücher acknowledges the support of his research on lignin degradation from the German Research Foundation (DFG).

Edited by: C. Rumpel

Reviewed by: X. Feng and one anonymous referee

\section{References}

Ahrens, B., Braakhekke, M. C., Guggenberger, G., Schrumpf, M., and Reichstein, M.: Contribution of sorption, DOC transport and microbial interactions to the ${ }^{14} \mathrm{C}$ age of a soil organic carbon profile: Insights from a calibrated process model, Soil Biol. Biochem., 88, 390-402, 2015.

Amelung, W., Brodowski, S., Sandhage-Hofmann, A., and Bo, R.: Combining biomarker with stable isotope analyses for assessing the transformation and turnover of soil organic matter, Adv. Agron., 100, 155-250, 2008.

Buurman, P., Peterse, F., and Almendros Martin, G.: Soil organic matter chemistry in allophonic soils: a pyrolysis-GC/MS study of a Costa Rican Andosol catena, Eur. J. Soil Sci., 58, 1330-1347, 2007.

Castellano, M. J., Mueller, K. E., Olk, D. C., Sawyer, J. E., and Six, J.: Integrating plant litter quality, soil organic matter stabilization, and the carbon saturation concept, Global Change Biol., 21, 3200-3209, 2015.

Cerli, C., Celi, L., Kaiser, K., Guggenberger, G., Johansson, M.B., Cignetti, A., and Zanini, E.: Changes in humic substances along an age sequence of Norway spriuce stands planted on former agricultural land, Org. Geochem., 39, 1269-1280, 2008.

Cerli, C., Celi, L., Kalbitz, K., Guggenberger, G. and Kaiser, K.: Separation of light and heavy fractions in soil - testing for proper density cut-off and dispersion level, Geoderma, 170, 403-416, 2012.

Chorover, J. and Amistadi, M. K.: Reaction of forest floor organic matter at goethite, birnessite and smectite surfaces, Geochim. Cosmochim. Ac., 65, 95-109, 2001.

Cornwell, W. K., Cornelissen, J. H. C., Amatangelo, K., Dorrepaal, E., Eviner, V. T., Godoy, O., Hobbie, S.E., Hoorens, B., Kurokawa, H., Prerez-Harguindeguy, N., Quested, H. M., Santiago, L. S., Wardle, D. A., Wright, I. J., Aerts, R., Allison, S. D., van Bodegorn, P., Brovkin, V., Chatain, A., Callaghan, T. V., Diaz, S., Garnier, E., Gurvich, D. E., Kazakou, E., Klein, J. A., Read, J., Reich, P. B., Soudzilovskala, N. A., Vaieretti, M. A., and Westoby, M.: Plant species traits are the predominant control on litter decomposition rates within biomes worldwide, Ecol. Lett., 11, 1065-1071, 2008. 
Cotrufo, M. F., Ineson, P., and Rowland, A. P.: Decomposition of tree leaf litters grown under elevated $\mathrm{CO}_{2}$ : Effect of litter quality, Plant Soil, 163, 121-130, 1994.

Cotrufo, M. F., Wallenstein, M. D., Boot, C. M., Denef, K., and Paul, E.: The Microbial Efficiency-Matrix Stabilization (MEMS) framework integrates plant litter decomposition with soil organic matter stabilization: do labile plant inputs form stable soil organic matter?, Global Change Biol., 19, 988-995, 2013.

Cronan, C. S.: Comparative effects of precipitation acidity on three forest soils: carbon cycling responses, Plant Soil, 88, 101-112, 1985.

Crow, S. E., Lajtha, K., Filley, T. R., Swanston, C. W., Bowden, R. D., and Caldwell, B. A.: Sources of plant-derived carbon and stability of organic matter in soil: implications for global change, Global Change Biol., 15, 2003-2019, 2009.

Dai, K. H., David, M. B., and Vance, G. F.: Characterization of solid and dissolved carbon in a spruce-fir Spodosol, Biogeochemistry, 35, 339-365, 1996.

Davis, J. A. and Gloor, R.: Adsorption of dissolved organics in lake water by aluminium oxide. Effect of molecular weight, Environ. Sci. Technol., 15, 1223-1229, 1981.

Dignac, M. F., Bahri, H., Rumpel, C., Rasse, D. P., Bardoux, G., Balesdent, J., Girardin, C., Chenu, C., and Mariotti, A.: Carbon13 natural abundance as a tool to study the dynamics of lignin monomers in soil: an appraisal at the Closeaux experimental field (France), Geoderma, 128, 3-17, 2005.

Don, A. and Kalbitz, K.: Amounts and degradability of dissolved organic carbon from foliar litter at different decomposition stages, Soil Biol. Biochem., 37, 2171-2179, 2005.

Duboc, O., Dignac, M.-F., Djukic, I., Zehetner, F., Gerzabrek, M. H., and Rumpel, C.: Lignin decomposition along an Alpine elevation gradient in relation to physicochemical and soil microbial parameters, Global Change Biol., 20, 2272-2285, 2014.

Dungait, J. A. J., Hopkins, D. W., Gregory, A. S., and Whitmore, A. P.: Soil organic matter turnover is governed by accessibility not recalcitrance, Global Change Biol., 18, 1761-1796, 2012.

Eusterhues, K., Rumpel, C., Kleber, M. and Kögel-Knabner, I.: Stabilisation of soil organic matter by interactions with minerals as revealed by mineral dissolution and oxidative degradation, Org. Geochem., 34, 1591-1600, 2003.

Eusterhues, K., Rumpel, C., and Kögel-Knabner, I.: Organomineral associations in sandy acid forest soils: importance of specific surface area, iron oxides and micropores, Eur. J. Soil Sci., 56, 753-763, 2005.

Eusterhues, K., Rumpel, C., and Kögel-Knabner, I.: Composition and radiocarbon age of HF-resistant organic matter in a Podzol and Cambisol, Org. Geochem., 38, 1356-1372, 2007.

Fellman, J. B., D'Amore, D. V., Hood, E., and Boone, R. D.: Fluorescence characteristics and biodegradability of dissolved organic matter in forest and wetland soils from coastal temperate watersheds in southeast Alaska, Biogeochemistry, 88, 169-184, 2008.

Filley, T., Hatcher, P. G., Shortle, W. C., and Praseuth, R. T.: The application of ${ }^{13} \mathrm{C}$-labeled tetramethylammonium hydroxide $\left({ }^{13} \mathrm{C}\right.$ TMAH) thermochemolysis to the study of fungal degradation of wood, Org. Geochem., 31, 181-198, 2000.

Fröberg, M., Berggren Kleja, D., and Hagedorn, F.: The contribution of fresh litter to dissolved organic carbon leached from a coniferous forest floor, Eur. J. Soil Sci., 58, 108-114, 2007.
Gallet, C. and Pellissier, F.: Phenolic compounds in natural solutions of a coniferous forest, J. Chem. Ecol., 23, 2401-2412, 1997.

Gauthier, A., Derenne, S., Dupont, L., Guilon, E., Largeau, C., Dumonceau, J., and Aplincourt, M.: Characterization and comparison of two ligno-cellulose substrates by ${ }^{13} \mathrm{C}$ CP/MAS NMR, XPS, conventional pyrolysis and thermochemolysis, Anal. Bioanal. Chem., 373, 830-838, 2002.

Gleixner, G.: Soil organic matter dynamics: a biological perspective derived from the use of compound-specific isotopes studies, Ecol. Res., 28, 683-695, 2013.

Gleixner, G., Poirier, N., Bol, B., and Balesdent, J.: Molecular dynamics of organic matter in cultivated soil, Org. Geochem., 33, 357-366, 2002.

Golchin, A., Clarke, P., Baldock, J. A., Higashi, T., Skjemstad, J. O., and Oades, J. M.: The effect of vegetation and burning on chemical composition of soil organic matter in a volcanic ash soil shown by ${ }^{13} \mathrm{C}$ NMR spectroscopy. I. Whole soil and humic fraction, Geoderma, 76, 155-174, 1997.

Goňi, M. A. and Hedges, J. I.: Lignin dimmers: Structure, distribution, and potential geochemical applications, Geochim. Cosmochim. Ac., 54, 4025-4043, 1992.

Grandy, A. S. and Neff, J. C.: Molecular C dynamics downstream: The biochemical decomposition sequence and its impact on soil organic matter structure and function, Sci. Total Environ., 404, 297-307, 2008.

Grünewald, G., Kaiser, K., Jahn, R., and Guggenberger, G.: Organic matter stabilization in young calcareous soils as revealed by density fractionation and analysis of lignin-derived constituents, Org. Geochem., 37, 1573-1589, 2006.

Guo, M. and Chorover, J.: Transport and fractionation of dissolved organic matter in soil columns, Soil Sci., 168, 108-118, 2003.

Hagedorn, F. and Machwitz, M.: Controls on dissolved organic matter leaching from forest litter grown under elevated $\mathrm{CO}_{2}$, Soil Biol. Biochem., 39, 1759-1769, 2007.

Hansson, K., Kleja, D. B., Kalbitz, K., and Larsson, H.: Amounts of carbon mineralised and leached as DOC during decomposition of Norway spruce needles and fine roots, Soil Biol. Biochem., 42, 178-185, 2010.

Hassouna, M., Massiani, C., Dudal, Y., Pech, N., and Theraulaz, F.: Changes in water extractable organic matter (WEOM) in a calcareous soil under field conditions with time and soil depth, Geoderma, 155, 75-85, 2010.

Hatton, P.-J., Castanha, C., Torn, M. S., and Bird, J. A.: Litter type control on soil $\mathrm{C}$ and $\mathrm{N}$ stabilization dynamics in a temperate forest, Global Change Biol., 21, 1358-1367, 2015.

Haumaier, L.: Benzene polycarboxylic acids - A ubiquitous class of compounds in soil, J. Plant Nutr. Soil Sci., 173, 727-736, 2010.

Heim, A. and Schmidt, M. W. I.: Lignin turnover in arable soil and grassland analysed with two different labelling approaches, Eur. J. Soil Sci., 58, 599-608, 2007.

Heim, A., Hofmann, A., and Schmidt, M. W. I.: Forest-derived lignin biomarkers in an Australian oxisol decrease substantially after 90 years of pasture, Org. Geochem., 41, 1219-1224, 2010.

Hernes, P. J., Kaiser, K., Dyda, R. Y., and Cerli, C.: Molecular trickery in soil organic matter: hidden lignin, Environ. Sci. Technol., 47, 9077-9085, 2013.

Hofmann, A., Heim, A., Christensen, B. T., Miltner, A., Gehre, M., and Schmidt, M. W. I.: Lignin dynamics in two ${ }^{13} \mathrm{C}$-labelled arable soils during 18 years, Eur. J. Soil Sci., 60, 250-257, 2009. 
Hunt, J. F., Ohno, T., He, Z., Honeycutt, C. W., and Bryan Dali, D.: Influence of decomposition on chemical properties of plantand manure-derived dissolved organic matter and sorption on goethite, J. Environ. Qual., 36, 135-143, 2007.

Jagadamma, S., Mayes, M. A., and Phillips, J. R.: Selective sorption of dissolved organic carbon compounds by temperate soils, PloS One 7, e50434, doi:10.1371/journal.pone.0050434, 2012.

Jardine, P. M., McCarthy, J. F., and Weber, N. L.: Mechanisms of dissolved organic carbon adsorption on soil, Soil Sci. Soc. Am. J., 53, 1378-1385, 1989.

Johansson, M.-B., Kögel, I., and Zech, W.: Changes in the lignin fraction of spruce and pine needle litter during decomposition as studied by some chemical methods, Soil Biol. Biochem., 18, 611-619, 1986.

Kaiser, K. and Kalbitz, K.: Cycling downwards - dissolved organic matter in soils, Soil Biol. Biochem., 52, 29-32, 2012.

Kaiser, K. and Zech, W.: Competitve sorption of dissolved organic matter fractions to soils and related mineral phases, Soil Sci. Soc. Am. J., 61, 64-69, 1997.

Kaiser, K. and Zech, W.: Dissolved organic matter sorption by mineral constituents of subsoil clay fractions, J. Plant Nutr. Soil Sci., $163,531-535,2000$.

Kaiser, K., Guggenberger, G., and Zech, W.: Sorption of DOM and DOM fractions to forest soils, Geoderma, 74, 281-303, 1996.

Kaiser, K., Guggenberger, G., and Haumaier, L.: Changes in ligninderived phenols, neutral sugars, uronic acids, and amino sugars with depth in forested Haplic Arenosols and Rendzic Leptosols, Biogeochemistry, 70, 135-151, 2004.

Kalbitz, K. and Kaiser, K.: Contribution of dissolved organic matter to carbon storage in forest mineral soils, J. Plant Nutr. Soil Sci., 171, 52-60, 2008.

Kalbitz, K., Schmerwitz, J., Schwesig, D., and Matzner, E.: Biodegradation of soil-derived dissolved organic matter as related to its properties, Soil Biol. Biochem., 35, 1129-1142, 2003a.

Kalbitz, K., Schwesig, D., Schmerwitz, J., Kaiser, K., Haumeier, L., Glaser, B., Ellerbrock, R., and Leinweber, P.: Changes in properties of soil-derived dissolved organic matter induced by biodegradation, Soil Biol. Biochem., 35, 1129-1142, 2003b.

Kalbitz, K., Schwesig, D., Rethemeyer, J., and Matzner, E.: Stabilization of dissolved organic matter by sorption to the mineral soil, Soil Biol. Biochem., 37, 1319-1331, 2005.

Kalbitz, K., Kaiser, K., Bargholz, J., and Dardenne P.: Lignin degradation controls the production of dissolved organic matter in decomposing foliar litter, Eur. J. Soil Sci., 57, 504-516, 2006.

Kalbitz, K., Meyer, A., Yang, R., and Gerstberger, P.: Response of dissolved organic matter in the forest floor to long-term manipulation o flitter and throughfall inputs, Biogeochemistry, 86, 301318, 2007.

Kawahigashi, M., Kaiser, K., Rodionov, A. and Guggenberger, G.: Sorption of dissolved organic matter by mineral soils of the Siberian forest tundra, Global Change Biol., 12, 1868-1877, 2006.

Keiluweit, M., Bougoure, J. J., Nice, P. S., Pett-Ridge, J., Weber, P. K., and Kleber, M.: Mineral protection of soil carbon counteracted by root exudates, Nat. Clim. Change, 5, 588-595, 2015.

Kiem, R. and Kögel-Knabner, I.: Contribution of lignin and polysaccharides to the refractory carbon pool in C-depleted arable soils, Soil Biol. Biochem., 35, 101-118, 2003.
Kinchesh, P., Powlson, D. S., and Randall, E. W.: ${ }^{13}$ C NMR studies of organic matter in whole soils: I. Quantitation possibilities, Eur. J. Soil Sci., 46, 125-138, 1995.

Kleber, M., Eusterhues, K., Keiluweit, M., Mikutta, C., Mikutta, R., and Nico, P. S.: Mineral-Organic Associations: Formation, Properties, and Relevance in Soil Environments, Adv. Agron., 130, 1-140, 2015.

Kleber, M., Nico, P. S., Plante, A., Filley, T., Kramer, M., Swansten, C., and Sollins, P.: Old and stable soil organic matter is not necessarily chemically recalcitrant: implications for modeling concepts and temperature sensitivity, Global Change Biol., 17, 1097-1107, 2011.

Klotzbücher, T., Filley, T. R., Kaiser, K., and Kalbitz, K.: A study of lignin degradation in leaf and needle litter using ${ }^{13} \mathrm{C}$-labelled tetramethylammonium hydroxide (TMAH) thermochemolysis: Comparison with $\mathrm{CuO}$ oxidation and van Soest methods, Org. Geochem., 42, 1271-1278, 2011.

Knicker, H.: Solid state CPMAS ${ }^{13} \mathrm{C}$ and ${ }^{15} \mathrm{~N}$ NMR spectroscopy in organic geochemistry and how spin dynamics can either aggravate or improve spectra interpretation, Org. Geochem., 42, 867890, 2011.

Knicker, H., Totsche, K. U., Almendros, G., and Gonzalez-Vila, F. J.: Condensation of burnt peat and plant residues and the reliability of solid-state VACP MAS ${ }^{13} \mathrm{C}$ NMR spectra obtained from pyrogenic humic material, Org. Geochem., 36, 1359-1377, 2005.

Kögel-Knabner, I.: The macromolecular organic composition of plant and microbial residues as inputs to soil organic matter, Soil Biol. Biochem., 34, 139-162, 2002.

Kögel-Knabner, I., Guggenberger, G., and Kleber, M.: Organomineral associations in temperate soils: integrating biology, mineralogy, and organic matter chemistry, J. Plant Nutr. Soil Sci., 171, 61-82, 2008.

Kothawala, D. N., van Wachenfeldt, E., Koehler, B., and Tranvik, L. J.: Selective loss and preservation of lake water dissolved organic matter fluorescence during long-term dak incubations, Sci. Total Environ., 433, 238-246, 2012.

Kramer, M. G., Sanderman, J., Chadwick, O. A., Chorover, J., and Vitousek, P. M.: Long-term carbon storage through retention of dissolved aromatic acids by reactive particles in soil, Global Change Biol., 18, 2594-2605, 2012.

Kraus, T. E. C., Dahlgren, R. A., and Zasoski, R. J.: Tannins in nutrient dynamics of forest ecosystems - a review, Plant Soil, 256, 41-66, 2003.

Kuzyakov, Y. and Blagdodatskaya, E.: Microbial hotspots and hot moments in soil: Concenpts and review, Soil Biol. Biochem., 83, 184-199, 2015.

Kuzyakov, Y., Bogomolova, I., and Glaser, B.: Biochar stability in soil: Decomposition during eigth years and transformation as assessed by compound-specific ${ }^{14} \mathrm{C}$ analysis, Soil Biol. Biochem., 70, 229-236, 2014.

Lajtha, K., Crow, S. E., Yano, Y., Kaushal, S. S., Sulzman, E., Sollins, P., and Spears, J. D. H.: Detrital controls on soil solution $\mathrm{N}$ and dissolved organic matter in soils: a field experiment, Biogeochemistry, 76, 261-281, 2005.

Lajtha, K., Bowden, R. D., and Nadelhoffer, K.: Litter and root manipulations provide insights into soil organic matter dynamics and stability, Soil Sci. Soc. Am. J., 78, 251-269, 2014.

Lehmann, J. and Kleber, M.: The contentious nature of soil organic matter, Nature, 528, 60-68, 2015. 
Lehmann, J., Kinyangi, J., and Solomon, D.: Organic matter stabilization in soil microaggegates: implications from spatial heterogeneity of organic carbon contents and carbon forms, Biogeochemistry, 85, 45-57, 2007.

Lehmann, J., Solomon, D., Kinyangi, J., Dathe, L., Wirick, S., and Jacobsen, C.: Spatial complexity of soil organic matter forms at nanometre scales, Nat. Geosci., 1, 238-242, 2008.

Leifeld, J. and Kögel-Knabner, I.: Soil organic matter fractions as early indicators for carbon stock changes under different landuse, Geoderma, 124, 143-155, 2005.

Mahieu, N., Randall, E. W., and Powlson, D. S.: Statistical analysis of published carbon-13 CPMAS NMR spectra of soil organic matter, Soil Sci. Soc. Am. J., 63, 307-319, 1999.

Mao, J. D., Hu, W. G., Schmidt-Rohr, K., Davies, G., Ghabbour, E. A., and Xing, B.: Quantitative characterization of humic substances by solid-state carbon-13 nuclear magnetic resonance, Soil Sci. Soc. Am. J., 64, 873-884, 2000.

Marschner, B. and Kalbitz, K.: Controls of bioavailability and biodegradability of dissolved orgaic matter in soil, Geoderma, 113, 211-235, 2003.

Marschner, B., Brodowski, S., Dreves, A., Gleixner, G., Gude, A., Grootes, P. M., Hamer, U., Heim, A., Jandl, G., Ji, R., Kaiser, K., Kalbitz, K., Kramer, C., Leinweber, P., Rethemeyer, J., Schäffer, A., Schmidt, M. W. I., Schwark, L., and Wiesenberg, G.: How relevant is recalcitrance for the stabilization of organic matter in soils?, J. Plant Nutr. Soil Sci., 171, 81-110, 2008.

Mason, S. L., Filley, T. R., and Abbott, G. D.: A comparative study of the molecular composition a grassland soil with adjacent unforested and afforested moorland ecosystem, Org. Geochem., 42, 1519-1528, 2012.

McDowell, W. H., Zsolnay, A., Aitkenhead-Peterson, J. A., Gregorich, E. G., Jones, D. L., Jödemann, D., Kalbitz, K., Marschner, B., and Schwesig, D.: A comparison of methods to determine the biodegradable dissolved organic carbon from different terrestrial sources, Soil Biol. Biochem., 38, 1933-1942, 2006.

McKnight, D. M., Bencala, K. E., Zellweger, G. W., Aiken, G. R., Feder, G. L., and Thorn, K. A.: Sorption of dissolved organic carbon by hydrous aluminium and iron oxides occurring at the confluence of Deer Creek with the Snake River, Summit County, Colorado, Environ. Sci. Technol., 26, 1388-1396, 1992.

Michalzik, B., Tipping, E., Mulder, J., Gallardo Lancho, J. F., Matzner, E., Bryant, C. L., Clarke, N., Lofts, S., and Vicente Esteban, M. A.: Modelling the production and transport of dissolved organic carbon in forest soils, Biogeochemistry, 66, 241264, 2003.

Mikutta, R., Mikutta, C., Kalbitz, K., Scheel, T., Kaiser, K., and Jahn, R.: Biodegradation of forest floor organic matter bound to minerals via different binding mechanisms, Geochim. Cosmochim. Ac., 71, 2569-2590, 2007.

Miltner, A., Bonbach, P., Schmidt-Brücken, B., and Kästner, M.: SOM genesis: microbial biomass as a significant source, Biogeochemistry, 111, 41-55, 2012.

Nakashini, T., Atarashi-Andoh, M., Koarashi, J., Saito-Kokubu, Y., and Hirai, K.: Carbon isotopes of water-extractable organic carbon in a depth profile of forest soil imply a dynamic relationship with soil carbon, Eur. J. Soil Sci., 63, 495-500, 2012.

Neff, J. C. and Asner, G. P.: Dissolved organic carbon in terrestrial ecosystems: synthesis and a model, Ecosystems, 4, 29-48, 2001.
Nguyen, C.: Rhizodeposition of organic $\mathrm{C}$ by plants: mechanisms and controls, Agronomie, 23, 375-396, 2003.

Nierop, K. G. J. and Filley, T. R.: Assessment of lignin and (poly)phenol transformations in Oak (Quercus robur) dominated soils by ${ }_{13} \mathrm{C}-\mathrm{TMAH}$ thermochemolysis, Org. Geochem., 38, 551-565, 2007.

Nierop, K. G. J., van Bergen, P. F., Buurman, P., and van Lagen, B.: $\mathrm{NaOH}$ and $\mathrm{Na}_{4} \mathrm{P}_{2} \mathrm{O}_{7}$ extractable organic matter in two allophanic volcanic ash soils of the Azores Islands - a pyrolysis GC/MS study, Geoderma, 127, 36-51, 2005.

Pausch, J., Tian, J., Riederer, M., and Kuzyakov, Y.: Estimation of rhizodeposition at field scale: upscaling of a ${ }^{14} \mathrm{C}$ labeling study, Plant Soil, 364, 273-285, 2013.

Pinney, M. L., Westerhoff, P. K., and Baker, L.: Transformations in dissolved organic carbon through constructed wetlands, Water Res., 34, 1897-1911, 2000.

Preston, C. M., Nault, J. R., and Trofymow, J. A.: Chemical changes during 6 years of decomposition of 11 litters in some Canadian forest sites. Part $2 .{ }^{13} \mathrm{C}$ abundance, solid-state ${ }^{13} \mathrm{C}$ NMR spectroscopy and the meaning of "lignin", Ecosystems, 12, 1078$1102,2009$.

Qualls, R. G. and Haines, B. L.: Geochemistry of dissolved organic nutrients in water percolating through a forest ecosystem, Soil Sci. Soc. Am. J., 55, 1112-1123, 1991.

Rasse, D. P., Dignac, M.-F., Bahri, H., Rumpel, C., Mariotti, A., and Chenu, C.: Lignin turnover in a agricultural field: from plant residues to soil-protected fractions, Eur. J. Soil Sci., 57, 530-538, 2006.

Remusat, L., Hatton, P.-J., Nico, P. S., Zeller, B., Kleber, M., and Derrien, D.: NanoSIMS study of organic matter associated with soil aggregates: advantages, limitations, and combination with STXM, Environ. Sci. Technol., 46, 3943-3949, 2012.

Rumpel, C., Eusterhues, K., and Kögel-Knabner, I.: Non-cellulosic neutral sugar contribution to mineral associated organic matter in top- and subsoil horizons oft wo acid forest soils, Soil Biol. Biochem., 42, 379-382, 2010.

Rumpel, C., Rodríguez-Rodríguez, A., González-Pérez, J. A., Arbelo, C., Chabbi, N., Nunan, N., and González-Vila, F.J.: Contrasting composition of free and mineral-bound organic matter in top- and subsoil horizons of Andosols, Biol. Fert. Soils, 48, 401-411, 2012.

Rumpel, C., Baumann, K., Remusat, L., Dignac, M.-F., Barre, P., Deidicque, D., Glasser, G., Lieberwarth, I., and Chabbi, A.: Nanoscale evidence of contrasted processes for root-derived organic matter stabilization by mineral interactions depending on soil depth, Soil Biol. Biochem., 85, 82-88, 2015.

Sanderman, J., Baldock, J. A., and Amundson, R.: Dissolved organic carbon chemistry and dynamics in contrasting forest and grassland soils, Biogeochemistry, 89, 181-198, 2008.

Schlesinger, W. H. and Andrews, J. A.: Soil respiration and the global carbon cycle, Biogeochemistry, 48, 7-20, 2000.

Schmidt, M. W. I., Torn, M. S., Abiven, S., Dittmar, T., Guggenberger, G., Janssens, I. A., Kleber, M., Kögel-Knabner, I., Lehmann, J., Manning, D. A. C., Nannipieri, P., Rasse, D., Weiner, S., and Trumbore, S. E.: Persistance of soil organic matter as an ecosystem property, Nature, 478, 49-56, 2011.

Schöning, I., Morgenroth, G., and Kögel-Knabner, I.: O/N-alkyl and alkyl $\mathrm{C}$ are stabilized in fine particle size fractions of forest soils, Biogeochemistry, 73, 475-497, 2005. 
Simpson, M. J. and Hatcher, P. G.: Overestimates of black carbon in soils and sediments, Naturwissenschaften, 91, 436-440, 2004.

Simpson, M. J. and Simpson, A. J.: The chemical ecology of soil organic matter molecular constituents, J. Chem. Ecol., 38, 768784, 2012.

Skjemstad, J. O., Clarke, P., Taylor, J. A., Oades, J. M., and McClure, S. G.: The chemistry and nature of protected carbon in soil, Aust. J. Soil Res., 34, 251-271, 1996.

Smebye, A., Alling, V., Vogt, R. D., Gadmar, T. C., Mulder, J., Cornelissen, G., and Hale, S. E.: Biochar amendment to soil changes dissolved organic matter content and composition, Chemosphere, 142, 100-105, 2016.

Sodano, M., Said-Pullicino, D., Fiori, A. F., Catoni, M., Martin, M., and Celi, L.: Sorption of paddy soil-derived dissolved organic matter on hydrous iron oxide - vermiculite mineral phases, Geoderma, 261, 169-171, 2016.

Sollins, P., Kramer, M. G., Swanston, C., Lajtha, K., Filley, T., Aufdenkampe, A. K., Wagai, R., and Bowden, R. D.: Sequential density fractionation across soils of contrasting mineralogy: evidence for both microbial- and mineral-controlled soil organic matter stabilization, Biogeochemistry, 96, 209-231, 2009.

Thevenot, M., Dignac, M.-F., and Rumpel, C.: Fate of lignins in soils: a review, Soil Biol. Biochem., 42, 1200-1211, 2010.

Tonneijck, F. H., Jansen, B., Nierop, K. G. J., Verstraten, J. M., Sevink, J., and De Lange, L.: Towards understanding of carbon stocks and stabilization in volcanic ash soils in natural Andean ecosystems of northern Ecuador, Eur. J. Soil Sci., 61, 392-405, 2010.
Toosi, E. H., Clinton, P. W., Beare, M. H., and Norton, D. A.: Biodegradation of soluble organic matter as affected by land-use and soil depth, Soil Sci. Soc. Am. J., 76, 1667-1677, 2012.

Torn, M. S., Trumbore, S. E., Chadwick, O. A., Vitousek, P. M., and Hendricks, D. M.: Mineral control of soil organic carbon storage and turnover, Nature, 389, 170-173, 1997.

Tuchman, N. C., Wetzel, R. G., Rier, S. T., Wahtera, K. A., and Teeri, J. A.: Elevated atmospheric $\mathrm{CO}_{2}$ lowers leaf nutritional quality for stream ecosystem food webs, Global Change Biol., 8, 163-170, 2002.

Uselman, S. M., Qualls, R. G., and Lilienfein, J.: Quality of soluble organic $\mathrm{C}, \mathrm{N}$, and $\mathrm{P}$ produced by different types and species o flitter: Root litter vs. leaf litter, Soil Biol. Biochem., 54, 57-67, 2012.

Vogel, C., Mueller, C. W., Höschen, C., Buegger, F., Heister, K., Schulz, S., Schloter, M., and Kögel-Knabner, I.: Submicron structures provide preferential spots for carbon and nitrogen sequestration in soils, Nat. Commun., 5, 2947, doi:10.1038/ncomms3947, 2014.

Wichern, F., Eberhardt, E., Mayer, J., Joergensen, R. G., and Müller, T.: Nitrogen rhizodeposition in agricultural crops, Soil Biol. Biochem., 40, 30-48, 2008.

Zech, W., Guggenberger, G., and Schulten, H.-R.: Budgets and chemistry of dissolved organic carbon in forest soils: effects of anthropogenic soil acidification, Sci. Total Environ., 152, 49-62, 1994. 